\title{
The Application of Engineering Education Thought to the Comprehensive Quality Training for Applied Undergraduate Talents
}

\author{
Jing Shu \\ Shandong Agriculture and Engineering University, Jinan Shandong, 250100, China
}

Keywords: Engineering education thought, Applied undergraduate universities, Comprehensive quality training of talents.

\begin{abstract}
At present, there are a lot of problems and loopholes in the talent training system of most applied undergraduate universities in China, which are mainly reflected in the following two aspects. Firstly, the teachers and leaders in these applied undergraduate universities pay much attention to students' theoretical teaching and academic achievements, but disregard the training and exercise of students' practical application ability, resulting in the applied undergraduates' low comprehensive quality. In addition, they don't establish perfect career plans, so that they cannot adapt to the social development trend quickly and look for jobs blindly. Secondly, the talent training mode for applied undergraduates is not corresponding to the demand standards of the current social and economic development for talents. Based on this phenomenon, in this paper, the author took the application of the engineering education thought to the comprehensive quality training for applied undergraduate talents as the theme, analyzed the basic conception of the engineering education thought, "learning for practice", and the basic status of current applied undergraduate universities in training talents' comprehensive quality, and finally elaborated the specific application of the engineering education thought to the comprehensive quality training for applied undergraduate talents.
\end{abstract}

\section{Introduction}

With the implementation of new course reform in China in recent years, most Chinese universities have voluntarily reformed their traditional teaching modes and teaching ideas with innovation, especially some applied undergraduate universities, which have strengthened the comprehensive quality training for students and the attention to practical application ability. Here the author will introduce the application of the engineering education thought to the applied undergraduate universities with the main purpose to enhance the comprehensive quality training for applied undergraduate students. Considering the basic status of the comprehensive quality training for applied undergraduate talents in China and the problems in the actual teaching process at present, and the change of demand for applied talents with strong practical application and high comprehensive quality in the current talent market, the applied undergraduate universities have been forced to reform the talent training mode and have made great progress. The engineering education thought was discovered and researched specially for solving the defects in the current talent training mode, which plays an important role in overthrowing the old education system, so as to train the talents with comprehensive quality, such as the combination ability of theory and practice and the innovative application ability. Therefore, the application of engineering education thought to the comprehensive quality training for applied undergraduate talents is not only an inevitable social development trend, but also an inevitable requirement of new course reform.

\section{Overview of the engineering education thought}

At present, the engineering education thought is an important choice and key direction for Chinese universities to implement measures for engineering reform and to explore their talent training modes, which is valued highly and applied widely by applied undergraduate universities especially. The engineering education thought was put forward by Mr. Mao Yisheng firstly, a Chinese famous engineering education expert and social activist, which was an intellectual achievement of his more 
than 70 years of educational practice research, and has significant practical significance for the higher education reform in China.

Mr. Mao Yisheng held the post of the president of Southeast University, Beiyang University and Hehai Engineering College concurrently in his early years with rich teaching management experience. During his tenure, Mao Yisheng adjusted the teaching equipment, teaching style, campus management, school affairs management and other aspects greatly, and asked the teachers of all departments to teach knowledge and disseminate truth with the teaching attitude of being tireless in teaching, being a model for others, and being realistic. What's more, Mao Yisheng asked teachers to focus on the combination of practice and theory and students' personalized development while giving lessons, so that students could fully master and understand every theoretical principle to achieve the purpose of learning for practice.

Through continuous exploration and improvement in the practice process of education and teaching, Mr. Mao Yisheng accumulated a lot of experience in educational teaching management and summarized a lot of scientific and complete teaching thought, which was the thought of engineering discussed in this paper. Just because the engineering education thought was discovered and put forward by Mao Yisheng based on his deep teaching experience and theory, it contains the thought content of many aspects, which is reflected in following aspects:

First of all, in the engineering education thought, students' practical application ability is valued, and teachers are required to have a complete and reasonable teaching plan that can highlight students' comprehensive practice quality in the teaching process.

Secondly, the talent training mode is established. According to the thought, we shall adhere to the training of students' comprehensive quality as the teaching focus, and establish a multi-stage and multi-layered university talent training mode combined with the teaching courses and students' learning characteristics.

Finally, the engineering education thought put forward by Mr. Mao Yisheng has something in common with the theory of "learning by doing" abroad, both of which emphasizes the importance of experience accumulation and learning for practice, and the core of combination of theory and practice. However, comparatively speaking, the application of Chinese engineering education thought will be applied more widely to the comprehensive quality training for applied undergraduate talents.

\section{The basic status of the comprehensive quality training for applied undergraduate talents}

Just as the name implies, applied undergraduate universities shall pay attention to the training of students' practical ability with the talent training mode, and ask students not only to have strong professional knowledge, but also to have excellent practical application ability, employability and entrepreneurial ability. The engineering education thought is established based on these requirements. However, at present, there are still many problems in the comprehensive quality training for talents in most Chinese applied undergraduate universities, which are mainly reflected in following two aspects:

\subsection{The design of education and teaching modes of applied undergraduate universities}

At present, applied undergraduate universities still focus on the explanation of professional theories, and despise the training and exercise of students' practical application ability in their education mode. According to the feedback of applied graduates who have worked in the society on their learning in universities, many of them think that the knowledge they learned in universities has lagged behind the demands of the society and market, which is shown in the simple and abstract teaching content, superficial explanation of practical cases without deep analysis, so that students cannot comprehend and master the professional knowledge deeply.

Another obvious problem is that the teachers in applied undergraduate universities don't guide students to plan their careers correctly in the daily teaching process with the current education and teaching mode, so that the applied graduates cannot choose appropriate jobs correctly and feel very blind and frustrated after entering the society. 


\subsection{The comprehensive quality training for applied undergraduate talents}

An obvious problem in the training of applied undergraduate talents is the lack of training and guidance of comprehensive quality for students. Many students only understand the cases in textbooks, but they cannot analyze and judge the cases in real life. In short, they lack the practical operation ability.

Secondly, nowadays, more and more recruiters or employers not only require college graduates to have solid professional theoretical knowledge, but also pay more attention to applicants' comprehensive quality, such as logical analysis ability, business communication ability, data processing ability and writing ability. Generally, those who have these abilities are more favored by recruiters. However, most Chinese applied undergraduate universities ignore the training of students' comprehensive quality in their objective of talent training, but pay attention to the enrollment rate and regional ranking, and fail to guide students to establish the consciousness of comprehensive quality and embody the engineering education thought in their course setting and teaching content. As thus, the applied graduates are eliminated by the society because it is difficult for them to adapt to the social development quickly after entering the society.

\section{The specific application of the engineering education thought to the comprehensive quality training for applied undergraduate talents}

With the change of the reform direction of universal education, in order to accord with the demands of market for talents better, many domestic applied undergraduate universities have improved their talent training methods and modes with innovation. Because the educational idea and methods in the engineering education thought are consistent with the requirements of new course reform and the social development trend, engineering education thought has been valued by applied undergraduate universities, and has provided effective ideas for these universities in training the talents with comprehensive quality.

\subsection{Confirm the objective of talent training according to market demand}

One characteristic of applied undergraduate universities is to cultivate the talents with comprehensive quality, strong application ability and good social adaptability for the society. Therefore, it is necessary to fully understand the needs of society and market for talents, which is also the direction and foundation of the applied undergraduate universities. In this premise, applied undergraduate universities shall establish a scientific and reasonable talent training mode, confirm the objective of talent training clearly, and reform their teaching content and teaching methods, to strive to cultivate the high-quality talents who can serve local economic and social development efficiently. In this way, besides helping universities build extramural practice bases with enterprises and institutions, it is beneficial for applied graduates to choose correct employment directions and goals and establish a career outlook of serving in the grass-roots unit.

\subsection{Pay attention to the combination of theory and practice and guide students to establish the correct view of job selection and view of employment}

The students in applied undergraduate universities will face two important choices after entering universities soon: one is to choose their majors, and the other is to choose the future employment goals. Students' majors determine their future employment directions directly, so these two factors are the most important in the training of applied undergraduate talents. In the current education system, most applied undergraduates mainly learn the basic theories of majors and don't learn much professional business deeply in the first two years at college. However, once these students find that their majors are not suitable for them or they are not interested in their majors when they learn professional courses in the third year, it is too late to change their majors. Besides this phenomenon, another phenomenon is that the applied graduates are easy to become over-ambitious when they select jobs, and they think they can be competent for the ideal jobs, but they find that the actual jobs are not suitable for themselves, which causes frequent job-hopping. Actually, this is a wrong view of 
job selection and employment. In this case, graduates not only are unable to find right jobs, but also waste much time.

Therefore, applied undergraduate universities shall help students find the most appropriate majors for them by implementing a series of effective measures when they distribute majors. For example, universities can organize teachers to carry out a major introduction course to help students understand the basic characteristics of each major and the employment trend. Meanwhile, they can arrange new students to attend classes with the senior students of each major, so that they can know whether they are interested in these majors in the teachers' explanation and the communication with the seniors. Of course, if possible, schools can properly arrange new students to conduct field visits in some enterprises of relevant industries that they will be work on in the future and experience the working environment and work content after entering the society, so as to find their most suitable majors and employment directions. The author thinks the last method is the most effective. If students can experience and practice various jobs in person through a short term of investigation in the first two years, it will influence students more directly and deeply than that of teachers' teaching and instructions, and will help students establish a correct view of career selection and employment more efficiently.

\subsection{Conduct the teaching-research-production cooperative education in virtue of project development or other forms}

The most important platform and approach for current applied undergraduate universities on the comprehensive quality training is the teaching-research-production cooperative education. Meanwhile, it is an effective measure for these universities to conduct scientific research and give play to the function of social service. In order to achieve the objective of applied undergraduate education on the comprehensive quality training for talents, we can bring the engineering education thought into the teaching process of applied undergraduate education, and realize the objective from the following aspects:

For those courses with strong professional practice and more comprehensiveness, teachers shall adjust the traditional teaching methods properly, and explore and research new and interesting teaching modes actively, so as to stimulate students' interest and enthusiasm in learning. For example, establish learning groups in the class to complete some representative projects by group discussion and cooperation. In addition to this, organize student to simulate competitions, so as to strengthen their understanding and mastery of professional knowledge in real and competitive environment, and train students' practical operation ability.

For the applied undergraduate universities with allowable conditions, the best way is to establish cooperative relations with enterprises or institutions to decide projects according to the current situation and problems of local economic development. In this way, students can apply the professional knowledge and theories learned in universities to the practice theory effectively and integrate theory with practice, so as to fully embody the application of engineering education thought to the comprehensive quality training for talents. Besides, the application of engineering education thought helps students achieve the smooth connection between market demand and life decision to a large extent, and enhances the communication and cooperation ability and practical application ability of applied undergraduates in professional project researches.

\section{Conclusion}

The rapid development of society and the dynamic changes of market demand have driven the applied undergraduate universities to improve and adjust their objectives of talent training. Based on the running characteristics of applied undergraduate universities and the market demand, the training of students' practical application ability, employability and entrepreneurial ability has become the teaching focus of all colleges and universities. Besides, the leaders and teachers in these universities have paid close attention to the function and influence of engineering education thought in the comprehensive quality training for applied undergraduate talents, which has become an important method and way for applied undergraduate universities to cultivate the talents with comprehensive 
quality. Undoubtedly, the application of engineering education thought to the college teaching will become an inevitable trend for the education and teaching development in the future.

\section{Acknowledgement}

This research was financially supported by University Teaching Reform Research Projects of Shandong Education Department, "Core curriculum reform research of facility agricultural science and engineering based on engineering capability cultivation" (2015M150).

\section{References}

[1] Liu Defang, Wang Xuhua, and Yang Cheng, Exploration and Practice of the Teaching System Centering on Ability Training for Training Applied Mechanical Engineering Talents, China Higher Education Research, 2009-11-20.

[2] Wang Qian, Application of Engineering Education Thought to the Comprehensive Quality Training for Applied Undergraduate Talents, Journal of Hubei University of Economics (Humanities and Social Sciences Edition), 2015-08-15.

[3] Fei Yi, a View on the Development Way of Applied Undergraduate Universities from the Perspective of Quality, Management Observer, 2016-04-25.

[4] Wang Ligong, Cai jun, and Huang Liying, Innovative Thinking on the Idea of Training Applied Undergraduate Talents, Course Education Research, 2017-02-03.

[5] Zhang Zhongshi, and Zhang Yu, Research on the Comprehensive Quality Training for Students in Applied Undergraduate Universities, Journal of Inner Mongolia Agricultural University (Social Science Edition), 2015-06-15. 